\title{
Policy and Governance Implications for Transition to NTFP-Based Bioeconomy in Kashmir Himalayas
}

\author{
Ishtiyak Ahmad Peerzada ${ }^{1,2, *(\mathbb{D})}$, James Chamberlain ${ }^{3, *}$, Mohan Reddy ${ }^{4}$, Shalini Dhyani ${ }^{2,5}$ (i) \\ and Somidh Saha 6,7 (D) \\ 1 Faculty of Forestry, Sher-e-Kashmir University of Agricultural Sciences and Technology of Kashmir, \\ Srinagar 191201, India \\ 2 Commission on Ecosystem Management (CEM), International Union for the Conservation of Nature (IUCN), \\ 1196 Gland, Switzerland \\ 3 Forest Service, Southern Research Station (USDA), Blacksburg, VA 24060, USA \\ 4 World Resources Institute (WRI), New Delhi 10016, India; nimmalamohan@gmail.com \\ 5 Critical Zone Research Group, CSIR National Environmental Engineering Research Institute (NEERI), \\ Nagpur 440020, India; shalini3006@gmail.com \\ 6 Research Group Sylvanus, Institute for Technology Assessment and Systems Analysis (ITAS), Karlsruhe \\ Institute of Technology (KIT), 76344 Karlsruhe, Germany; somidh.saha@kit.edu \\ 7 Institute of Forest Sciences, Albert Ludwig University of Freiburg, 79085 Freiburg, Germany \\ * Correspondence: drishtiyak@skuastkashmir.ac.in (I.A.P.); james.l.chamberlain@usda.gov (J.C.)
}

check for

updates

Citation: Peerzada, I.A.;

Chamberlain, J.; Reddy, M.; Dhyani,

S.; Saha, S. Policy and Governance

Implications for Transition to

NTFP-Based Bioeconomy in Kashmir

Himalayas. Sustainability 2021, 13,

11811. https://doi.org/10.3390/

su132111811

Academic Editors: Zuzana Dobsinska and Ivana Zivojinovic

Received: 31 August 2021

Accepted: 22 October 2021

Published: 26 October 2021

Publisher's Note: MDPI stays neutral with regard to jurisdictional claims in published maps and institutional affiliations.

Copyright: (c) 2021 by the authors. Licensee MDPI, Basel, Switzerland. This article is an open access article distributed under the terms and conditions of the Creative Commons Attribution (CC BY) license (https:/ / creativecommons.org/licenses/by/ $4.0 /)$.

\begin{abstract}
Forests of Jammu and Kashmir (J\&K) have a rich diversity of valuable non-timber forest products (NTFP) that local communities extract for their sustenance and income. The region is home to over $60 \%$ of species recognized for novel bio-medicinal properties in the Indian Himalayas. There is significant national and international demand for these species, providing income and employment for more than $60 \%$ of the population of J\&K. Despite this, NTFP are not adequately recognized for their contributions to rural livelihoods and the regional economy due to the lack of appropriate policy and governance mechanisms. In this study, we embrace a bioresource vision to examine challenges and opportunities for transition to a sustainable bioeconomy in J\&K. Selected NTFP were considered for valuation to showcase their bioeconomy potential using two approaches. First, we used the 'market price method' to estimate the contribution of NTFP to the local economy. Second, the 'maximum willingness to pay method' was used to project the bioeconomy potential of NTFP in the region. The analysis reveals that local communities' revenues could increase by as much as 18 times their current price with appropriate actions to include NTFP. However, to realize this potential, policies and governance frameworks based on increased access and benefit sharing with inclusive institutional models would support the transition of the local economy into a bioeconomy. Fostering public-community partnership by improving the local participation of producers and processors in NTFP value chains for overcoming the existing governance barriers is needed.
\end{abstract}

Keywords: NTFP diversification; bioeconomy; participatory forestry; livelihoods; inclusive governance framework

\section{Introduction}

Non-timber forest products (NTFP) are goods of biological origin, including medicinal plants, mushrooms, and provisioning ecosystem services other than timber derived from forests, other wooded lands, and trees outside forests [1]. During the late 1980s and the early 1990s, NTFP were acclaimed to have tremendous potential for rural livelihood improvement [2,3], income generation [4-6], food security [7,8], primary health care [9-11], and forest conservation $[1,6,12,13]$. Since then, the diverse NTFP management systems have shown a relatively less negative impact on forests than logging $[14,15]$, by sustaining high forest diversity [16], helping in the adaptation to climate change [17], sheltering germplasm for regeneration [18], and improving the biotic and abiotic resistance of crop 
varieties $[19,20]$. Moreover, the contributions of NTFP have been acknowledged in the global developmental agenda of international organizations $[12,21]$ and commitments $[9,22]$ to achieve conservation and rural development by increasing the value of forest resources to local communities for poverty alleviation $[1,23]$.

NTFP have a tremendous economic significance, particularly for the world's rural poor, and are used, consumed, and traded by billions of people [24,25]. Around 80\% of the population of developing countries depends on plant-based traditional medicine for primary healthcare [25]. In some cases, upto $96 \%$ of the value of forest products are derived from NTFP and related services [26]. NTFP accounts for about $40 \%$ of the income of $60-80 \%$ of forest dwellers [27]. The Food and Agriculture Organization (FAO) estimates the contribution of NTFP at US\$88 billion, with an annual growth rate of $15-25 \%$, and demand is likely to increase to more than US $\$ 5$ trillion by 2050 [28].

India has a vibrant, dynamic, and large industry based on NTFP. About 1178 medicinal plant species are in trade. More than 240 species, mostly from the Indian Himalayan region, have demand of more than 100 metric tons, annually [29]. The consumption of herbal raw materials in India is estimated at 512,000 MT with a corresponding trade value of US\$734.3 million [29]. "Minor forest products" contribute over 50\% of the forest revenues and $70 \%$ of the export income from forest products in India [30]. However, estimates of trade at local, regional, and global levels are underestimated as NTFP are traded mostly in informal markets $[28,31,32]$. This has resulted in poor representation in national and international statistics $[25,26,28,33]$, mostly due to deficiencies in defined structures and standards $[23,34]$.

Sustainable use and management of NTFP, therefore offer socio-ecologically acceptable economic opportunities for forest conservation, income generation, and livelihood diversification of forest-dependent communities [35,36]. Evidence accumulated in recent decades on the sustainable bioeconomy potential of NTFP $[31,37,38]$ reinforces that claim, and has astonishingly encouraged both scientists and policy makers to look at the NTFP more considerably [35,39].

\subsection{Policy and Governance Complexity of NTFP}

Even though NTFP have been on the agenda of policy discussions of prominent international forums, treaties, and ongoing global assessments (e.g., Intergovernmental Panel on Biodiversity and Ecosystem Services thematic assessment of the sustainable use of wild species), there is limited information on NTFP specific policies at international [22], national, or regional levels [32]. The substantial contribution of NTFP to rural livelihoods has been disregarded in regulatory and management frameworks [24,40], as they are mostly collected by the rural poor or indigenous and local communities that represent the most marginalized groups of the society [34]. Many NTFP have lower industrial demand than forest products considered by governments [18] due to fragmented value chains and competing regulatory institutions [31]. A lack of clarity on products or species being regulated and the absence of inclusive governance that ensures consultations on these issues with forest fringe communities, collectors, and other stakeholders [31] has been a major bottleneck. The situation is further complicated by poor enforcement of policies and meager resource allocation to the sector due to the lack of interest in alleged 'minor forest products' $[40,41]$.

Moreover, NTFP have diverse ecological niches, usages, markets, and trade practices and are primarily managed through complex forest policies, hence not sufficiently addressed in regulatory frameworks. Despite being the primary motivating factor for local participation in forest management, policy, and governance frameworks for including NTFP have not received due attention in most developing countries [35] including India. Forest policies prioritized the production and protection of timber rather than developing forests as holistic ecosystems for diverse products and services [42]. The lack of clear regulatory policies and obstructive governance mechanisms remain the main barriers for the formal development of the NTFP sector [1]. 
In view of ever-increasing industrial demand, NTFP are being integrated into new conservation and development strategies, including environmental accounting, payment for ecosystem services, valuation of biodiversity [43], and bioeconomy [44]. This substantiates that commercialization of NTFP in emerging global markets holds a promise, provided fundamentals like inclusive policies, good and interactive governance, clear tenure rights, and sustainable resource extraction that help sustainably managed resources, and equitable markets are ensured $[26,45]$. The foremost need is to recognize the contributions of NTFP in state accounts and to have NTFP-specific policies to achieve socioeconomic and ecological benefits for the sector that includes multiple stakeholder groups. This will help to spur the transition towards a market-based sustainable bioeconomy with the increased use of NTFP to maintain environmental quality.

\subsection{Transition to NTFP-Based Bioeconomy}

Non-timber forest products, especially medicinal plants have significant roles in the conservation of genetic diversity, and producing novel chemical compounds [40,46]. NTFP are no longer recognized as food, fodder, and medicine of the poor only. Their contributions to foreign exchange earnings [47-49], driven by the increasing consumer demand for diversified bioactive compounds and products for pharmaceutical, nutraceutical, cosmeceutical, food, and beverage industries $[10,50,51]$ are readily identified. Apart from their demand in the traditional healthcare systems of developing nations, the bio-based pharmaceutical industry with annual sales of around US $\$ 1$ trillion is of a larger magnitude than the raw botanical industry [24,51]. Moreover, close to $50 \%$ of medicines are derived from natural products [52].

Given the onset of the worst financial crisis due to challenges such as population explosion, ever-increasing demand for food, water, and healthcare needs, over-exploitation of resources [53], human-induced climate change, and the recent pandemic (SARS-CoV19), bioeconomy is expected to provide opportunities for more environment-friendly raw material sourcing, primarily based on renewable and recycled resources [54]. Bioeconomy is based principally on efficient bioresource use and production involving alternatives to fossil fuels through technological innovations. Hence, bioeconomy-driven development has been classified based on bioresource availability [25]. Countries with vast bioresources focus on economic and social development by manufacturing, while countries with limited bioresources concentrate on technology-driven systems and business models [25]. However, other factors, such as policy context, public awareness of a climate responsive economy, and governance frameworks, affect possible development trajectories [55-57]. In bioresource rich low- and high-income countries, NTFP value chains are more relevant to forestdependent communities for income generation, livelihood improvement, and poverty alleviation $[44,57]$.

Hence, the forest sector offers diverse renewable bioresources to fulfill the socioeconomic and environmental objectives of emerging bioeconomies $[25,55,56]$. The global forest sector market is valued at US\$468 billion with a continuous contribution to local livelihoods, national economies, and international trade [58]. Moreover, the bio-based materials derived from forests can directly support upto $10 \%$ additional employment and 4-9 times more added value than traditional energy $[59,60]$. Therefore, the forest-based bioeconomy has potential for modeling green growth by providing new bio-products (Figure 1) such as advanced NTFP [61-63]. 


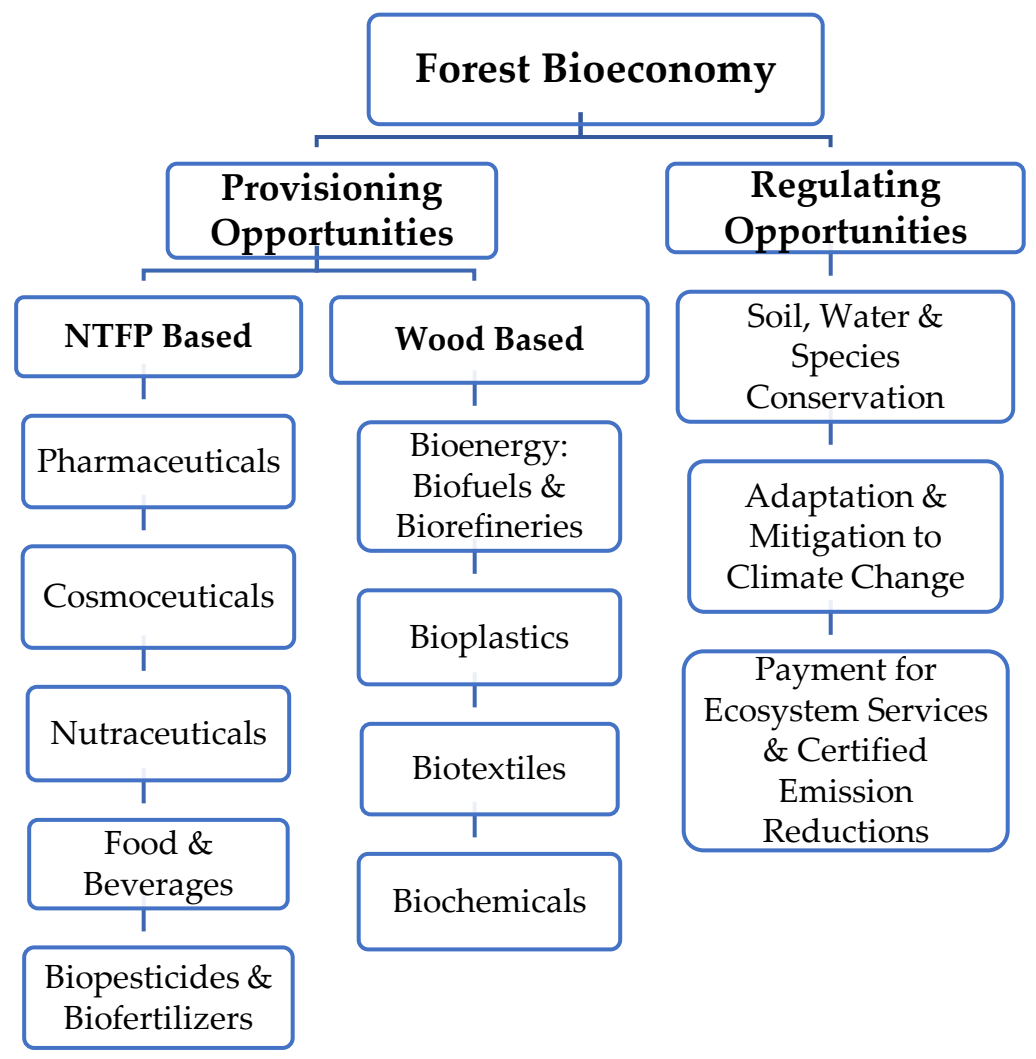

Figure 1. Forest and NTFP-based Bioeconomy. Source: Adopted and modified from Piplani, 2021; Baincolillo et al., 2020; Luc and Suzanne, 2003.

The forest-based bioeconomy is nascent in India and, therefore, there is little evidence in national policies or research agenda. The Ministry of Science and Technology, Government of India, issued The Bioenergy Roadmap 2012 and National Biotechnology Development Strategy 2015-2020 focusing principally on the development of biotechnology aspects of the energy and pharmaceutical sectors [64]. The Indian bioeconomy has been estimated at US $\$ 42$ billion, wherein US $\$ 19$ billion is contributed by the biotechnology industry [65]. With an average growth rate of $25 \%$, India's biotechnology industry is focused on achieving aUS\$100-billion bioeconomy by 2025 [66].

Owing to its diverse phytogeography and climatic conditions, Indian Himalayan states, particularly J\&K, could contribute significantly towards this growth. Harnessing such opportunities will require flexible policy, governance, and financing mechanisms for a transition to a NTFP-based bioeconomy $[67,68]$. In addition, a proactive collaboration between policymakers, regulators, scientists, entrepreneurs, and local communities will be critical for shaping an inclusive forest vis-à-vis NTFP-based bioeconomy. Three visions $[69,70]$ for a forest-based bioeconomy have been espoused: (i) a biotechnology vision, emphasizing the increased application of biotechnology in research and commercialization of biomass; (ii) a bioresource vision, focusing on the diversification of biological raw materials like NTFP with emphasis on processing, upgrading, and establishing new value chains; and (iii) a bioecology vision, through sustainability and ecological processes for the optimal use of energy and nutrients, promotion of biodiversity while mitigating soil degradation [69,71-73].

This study embraces the bioresource vision, focusing on NTFP, motivated by the potential to stimulate rural development by producing new bioproducts. Economic activities pertaining to NTFP like cultivation, processing, and diversification of value-added products will influence rural employment and development, and thus support transition to a bioeconomy. Such transition will require transformation in production, processing, marketing, and distribution from traditional value chains to highly sophisticated global 
supply chains [74]. We examine the assumption that NTFP have potential as significant contributors to the bioeconomy $[44,55]$ and provide opportunities to address environmental issues, including the sustainable use of biodiversity and habitat loss [25].

\section{Research Question and Objectives}

J\&K was the first region in the Indian subcontinent to frame a law (Kuth Act, 1978 Samvat) for the protection of valuable medicinal plants way back in 1921 CE. However, later on, its forest policies and management practices focused only on the timber-oriented forestry guided by economic priorities [75]. Despite a substantial role in the regional ecology and economy, NTFP have never been recognized in the state domestic product (SDP) due to lack of a proper resource valuation, appropriate policy, and governance mechanisms [76]. The information available on the volume of NTFP harvested, consumed, and traded from the region's forests is inadequate for planners and policymakers to recognize the contribution from the sector. Except for a few isolated attempts to assess the impacts, roles, and potential of NTFP for livelihood improvement, forest conservation, and revenue generation in the region, overall there is little information available [32]. Therefore, this study attempts to critically evaluate the forest policies, governance structure, and their impacts on the development of the NTFP sector, rural livelihoods, forest conservation, and the regional economy. Our aim is to identify challenges and advance policy and a governance framework for the transition to an NTFP-based sustainable bioeconomy in J\&K.

\section{Materials and Methods}

\subsection{Study Area}

For this study, Jammu, Kashmir, and Ladakh are considered as one state, although the area is divided into two union territories (Jammu and Kashmir, and Ladakh). J\&K constitutes an area of $222,236 \mathrm{~km}^{2}$, which is $6.76 \%$ of the geographical area of India. The state is strategically located in the North-western Himalayan range between $32^{\circ} 17^{\prime} \mathrm{N}$ to $37^{\circ} 05^{\prime} \mathrm{N}$ latitude and $72^{\circ} 31^{\prime} \mathrm{E}$ to $80^{\circ} 20^{\prime} \mathrm{E}$ longitude. It is bordered by China in the East, Pakistan in the West, Afghanistan in the North, and the Indian states of Punjab and Himachal Pradesh in the South and Southeast [77]. As per the 2011 Census, the population of J\&K was 12.54 million, and this included 3.43 million (27.38\%) urban and 9.11 million $(72.62 \%)$ rural population. In the rural population, about 1.49 million $(11.91 \%)$ were members of the local indigenous population. Out of 22 districts in the state, 14 are designated as hill districts. The recorded forest area of $J \& \mathrm{~K}$ is $20,230 \mathrm{~km}^{2}$, which constitutes $19.95 \%$ of its geographical area. Reserve forests comprise $17,643 \mathrm{~km}^{2}$, protected forests make up $2551 \mathrm{~km}^{2}$, and unclassed forests constitute $36 \mathrm{~km}^{2}$ of the recorded forest area. The per capita forest area in $\mathrm{J} \& \mathrm{~K}$ is 0.16 hectare [78].

The region is primarily an agrarian economy, with most of the population relying on agriculture and horticulture for sustenance and livelihood. However, the region's physiography inflicts several limitations on agriculture and allied sectors [77]. Hence, a large section of the rural population depends on forest resources for their livelihood [32]. The land-use pattern (Figure 2) in the state, which was purely agricultural, has changed from agri-horticultural to silvi-pastoral with marginal returns [32].

People of the region extract NTFPs such as medicinal plants, mushrooms, edible fruits, flowers, fodder, fiber, fuelwood, small wood for agricultural implements, material for basketry, and traditional fire pots (Kangri) for their sustenance. Kangri is an important heating source of more than 6.5 million inhabitants of Kashmir. 


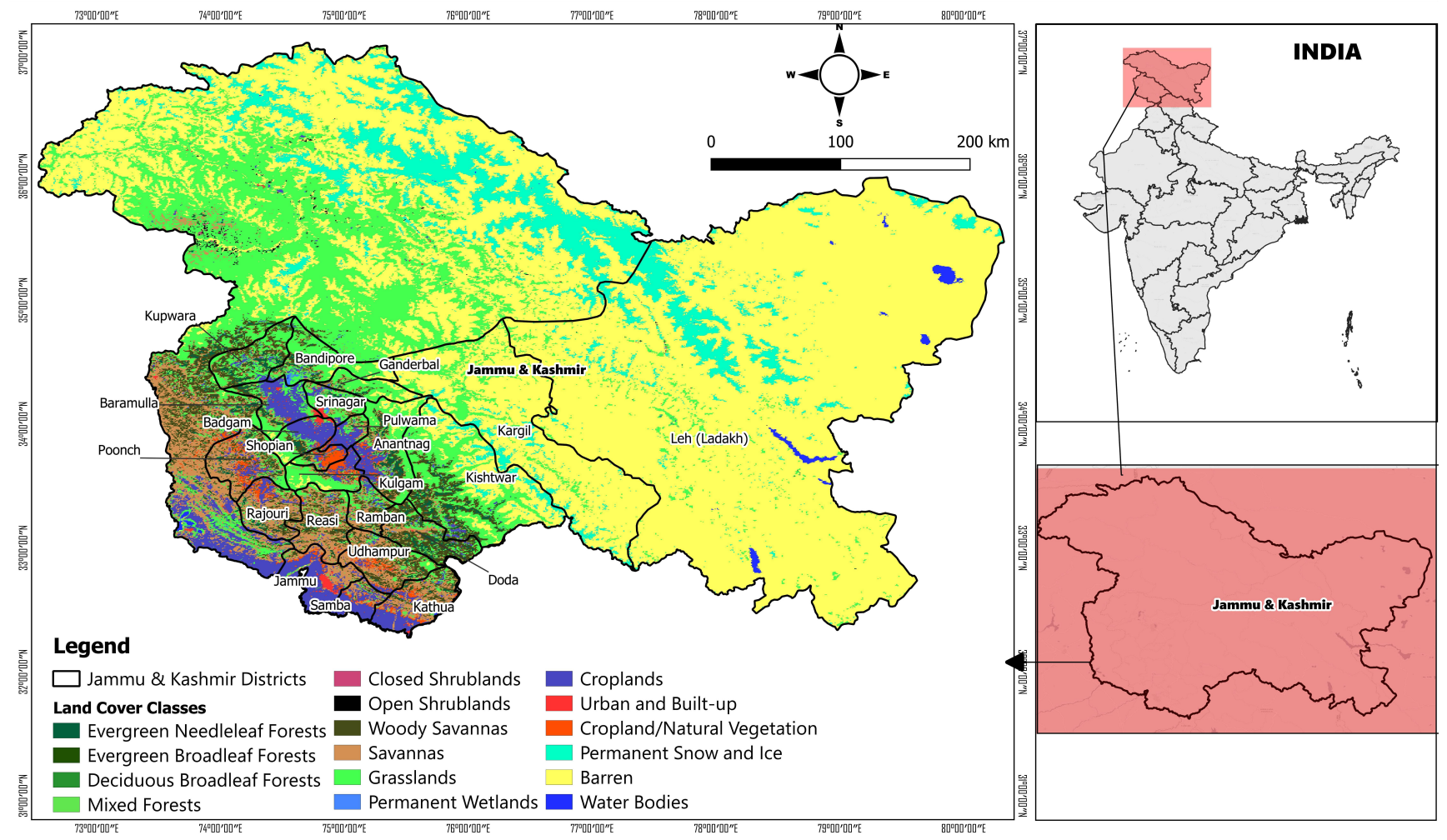

Figure 2. Land-pattern Map of Jammu and Kashmir, India. Source: MODIS Land cover data, APA format, accessed on 11 October 2021.

\subsection{Methods}

An extensive literature investigation was performed to review the documents consisting of research publications, articles, forest policies, notifications, and published and unpublished reports available at the library of Faculty of Forestry, SKUAST Kashmir. Series of publications (statistics, conference proceedings, and research papers) about international, national, and regional reports on the subject (with selected keywords NTFP, livelihood, trade, economics, governance, policy, bioeconomy, forest bioeconomy, and NTFP-based bioeconomy) were searched, prioritized, and downloaded from the internet using searching engines and online sources like ResearchGate, Google Scholar, and Scopus, etc. Abstracts of around 143 downloaded publications were screened and 86 publications relevant to the objective of this study and our particular interest to understand the various prospects, implications, and data gaps of a mainstream NTFP-based bioeconomy were considered for thorough analysis (Table 1). Considering that we had only 86 research papers, articles, reports etc. related to the context that we identified, all the abstracts were explored individually instead of only relying on the search engines, so as to obtain a better perspective on discussions and analysis carried out in these 86 documents. So, moving from the detailed bibliometric analysis, we conducted the systematic research review to be sure that our expectations were met from the references we chose for the detailed review. The credibility of each article was the context and analysis performed to address the issue of NTFP trade, governance gaps, policy implications and mainstreaming NTFP-based bioeconomy, and similarity of the situation from where these cases were reported and discussed. 
Table 1. Type and number of publications reviewed.

\begin{tabular}{ccc}
\hline Research Areas and Key Words Searched & $\begin{array}{c}\text { No. Publications } \\
\text { Downloaded }\end{array}$ & $\begin{array}{c}\text { No. of Publications } \\
\text { Reviewed }\end{array}$ \\
\hline NTFP Policy, Governance and Economics & 82 & 47 \\
\hline Bioeconomy with focus on forestry and NTFP & 45 & 23 \\
\hline Forest Bioeconomy Policy and Governance & 11 & 11 \\
\hline NTFP economics and trade in J\&K & 05 & 05 \\
\hline NTFP Policy in J\&K & 00 & 00 \\
\hline
\end{tabular}

The regional forest policies, acts, and rules were downloaded from the official website of the J\&K Forest Department (http:/ / www.jkforest.gov.in/act_rulesn.html accessed on 12 July 2020) to evaluate and determine their objectives, relevance, and impact on the NTFP sector till the year 2019-2020. The J\&K Forest Act, 1987 Samvat (1930 CE.), The Kuth Act, 1978 Samvat (1921 CE), J\&K State Forest Corporation Act, 1978, J\&K State Forest Policy, 2010, J\&K State Biodiversity Rules, 2015, and J\&K (Rehabilitation of Degraded Forests and Village Plantation) Rules, 1992 were thoroughly examined for their significance in the development of the NTFP sector for livelihood improvement, forest conservation, and revenue generation. In addition, the recently implemented Central laws in J\&K, i.e., Indian Forest Act, 1927 with Amendments, and Forest Rights Act, 2006 were also analyzed.

Accordingly, to ascertain the impact of forest policies and governance mechanism on the development of the NTFP sector and the challenges in transition to an NTFP-based sustainable bioeconomy, the responses from key informants were collected through semistructured interviews using the bellwethers approach [79]. Key informants were selected to provide a diverse array of perceptions across stakeholders. These people, although not comprehensive of society, provide valuable insights into impacts of forest policies. The type and number of bellwethers or "key informants" were drawn from the following departments and sectors Table 2:

Table 2. Type and number of bellwethers ${ }^{1}$ interviewed.

\begin{tabular}{ccc}
\hline S. No. & Type of Bellwethers & No. of Respondents \\
\hline 1. & $\begin{array}{c}\text { Resource managers (forest officials) J\&K forest } \\
\text { department, state forest research institute, } \\
\text { medicinal plants board, horticulture department } \\
\text { and social forestry department }\end{array}$ & 39 \\
\hline 2. & $\begin{array}{c}\text { Subject experts from SKUAST Kashmir, } \\
\text { CSIR-Indian Institute of Integrative Medicine } \\
\text { (IIIM), Kashmir University }\end{array}$ & 11 \\
\hline 3. & Primary collectors from ethnic group communities \\
i.e., Gujjar, Bakarwal and Shina tribe & 90 \\
\hline 4. & Traditional healers (Hakeems, Veds and Amchies) & 12 \\
\hline 5. & Traders (Suppliers, aggregators and traders) & 17 \\
\hline
\end{tabular}

${ }^{1}$ Bellwethers are influential and knowledgeable leaders in the public and private sector whose opinions about policy issues carry substantial weight. The bellwethers approach pioneered by the Harvard Family Research Project involves semi-structured interviews with bellwethers, but with an important twist. Instead of asking direct questions on specific issues, interview questions initially create room for a wide range of unprompted responses (HFRP, 2007).

A two-day state level symposium was organized during 19-20 March 2015 on “Prospects and challenges of domestication and commercialization of non-timber forest products (NTFP) including bamboos in J\&K" for the collection of additional insights and perceptions. A special session was convened on the impacts of forest policies on the development 
of the NTFP sector for the improvement of livelihood, forest conservation, and revenue generation.

NTFP trade data collected from the consultations, departmental statistics, and research studies were categorized into species-wise standardized units (Mt/yr) in keeping with the view of estimating the overall annual trade volume and value. We acknowledge that these traded values may not fully represent the actual market values due to various discounting factors like arbitrary margins being charged by the various intermediaries [29,32] Therefore, to showcase the bioeconomic potential considering the current dependence and governance frameworks, selected NTFP were considered for this study. Accordingly, the total economic value (TEV) approach was used to capture the use value (UV) through valuation techniques [26,80-82].

$$
\mathrm{TEV}_{\text {fes }}=\mathrm{UV}+\mathrm{Non}-\mathrm{UV}
$$
(BV)

UV = Direct Use + Indirect Use; and Non-UV = Option + Existence + Bequest Value

Since bioeconomy generally considers only $\mathrm{UV}$, such as tangible and direct values, the indirect value and non-UV, such as bequest value, existence value, and optional value, are omitted [66]. The existing economic value is determined by the market price method [83].

$$
\mathrm{TEV}_{\text {fes }}=\mathrm{Qm}(\mathrm{Pm})-\mathrm{C}
$$

where

$\mathrm{Tv}=$ Total value of product,

$\mathrm{Qm}=$ Quantity of goods extracted, estimated using studies conducted in the region and trade statistics

$\mathrm{Pm}=$ Forest gate price of goods; based on the pricing data from the NTFP collectors

$\mathrm{C}=$ Transaction costs; for calculation purposes, it is assumed to be zero

There is no standard methodology for estimating bioeconomic potential or allowing the comparison of bioeconomy contribution to GDP [25]. Therefore, for this study, the maximum bioresource potential and maximum willingness to pay (MWP) methods were used for projecting the final bioeconomic potential [84] of the selected NTFP. In bioresource economic activities, the local community and gatherers are not aware of the potential use and actual value of the products. On the other hand, the end-users, i.e., the industries, are aware of the value of the resources [76]. Therefore, the MWP for bioresources is estimated at a floor price at their collection point as a 'real value'. Through this method, the bioeconomic potential is estimated in terms of the price of raw materials, rather than targeting the final products percentage share, which is always subjective and non-transparent.

$\mathrm{T}$ Bioeconomic Potential $=\mathrm{N} 1($ Resource Potential $\times \mathrm{MWP})+\ldots \ldots \ldots+\mathrm{Nn}$ where

$\mathrm{N}=$ Refers to the selected product/medicinal plant 1

Resource potential has been estimated using the standard extrapolation method based on the per hectare value of NTFP collected in each forest area suitable to the growth of that species based on the altitude, geomorphology and forest cover (tons).

MWP is assumed as the prevailing gate price of purchasing the produce/medicinal plant (USD Price per Ton).

\section{Results}

\subsection{Literature and Policy Review}

The review of literature revealed that the forests are an integral part of the existence and cultural legacy of the people in J\&K since ages. Owing to its varied agroclimatic and topographic features, the forests of J\&K have a rich diversity of valuable NTFP. The region is home to more than 1123 valuable medicinal plants [85], which comprise $64 \%$ 
of the total species recognized for novel medicinal properties in the Indian Himalayan region [86,87], and about 50\% species are mentioned in British pharmacopeia [88]. Out of the total NTFP extracted by the people of J\&K, more than $95 \%$ are sourced from the forests and the rest is secured from agroforestry and homestead forestry [78]. In some cases, almost all species and products traded (viz, Aconitum heterophyllum, Arnebia benthamii, Trillium govanianum, etc.) are extracted from the natural forest reserves [32], as these species are found at high altitudes and have a comparatively long gestation period. NTFP growing in the region have a huge demand in national and international markets, and are source of food, nutrition, medicine, income, and employment generation for more than $60 \%$ local population $[32,77,87]$. The growing industrial demand and reliance of rural communities (particularly nomads, i.e., Gujjars and Bakarwals) on these products clearly indicate that there is a significant contribution of NTFP to the local economy. However, the use of NTFP vis-à-vis medicinal plants in the region has assumed wider dimension with the passage of time, as the people are now more interested in trade of products for livelihood and income generation than domestic consumption $[76,89]$.

Even though not fully recognized, the NTFP-sector is reported to be contributing to the livelihood and income generation of $50-60 \%$ population of the region. It is estimated that more than $60 \%$ people in the forest fringe villages of Langate Forest Division of Kashmir derive their household income from NTFP (like Morchella esculenta, Trillium govanianum, Saussurea lappa, and Aconitum heterophyllum, etc.) [32]. A similar study [77] revealed that NTFP contribute to $66.97 \%$ household income of the wicker workers (using species like Salix triandra, Salix viminalis, Parrotia jacquemontiana, Indigofera pulchella, Cotoneaster bacillaris, etc.), in the Pulwama district; $57.19 \%$ of anardana (Punica granatum) extractors in the Ramban district, and $43.56 \%$ of chilgoza (Pinus gerardiana) collectors in the Paddar valley of the Kishtwar district of J\&K.

The estimated value of NTFP per hectare of forestland for J\&K (US\$98.80) is much higher than the all-India average (US\$22.42) [90]. As per the 2018-2019 estimates of the Forest Department, the value of NTFP excluding fuelwood in J\&K was US $\$ 249,238.98$ [78] (Table 3). The common species extracted by J\&K forest department are Morchella esculenta, Punica granatum, Berberis lyceum, Artemisia absinthium, Podophyllum hexandrum, Jurinea dolomiaea, Saussurea lappa, Dioscorea deltoidea, and Viola odorata, etc. The extraction and marketing are carried out by a tender-cum-auction system through contractors on payment of a bid amount to the Forest Department. The contractor (often one person), after paying the bid amount, gets permission for the collection of certain NTFP from forests on a royalty basis.

Table 3. Value of NTFP ${ }^{1}$ (excluding fuelwood) generated by the J\&K Forest Department from 2003-2004 to 2018-2019.

\begin{tabular}{ccc}
\hline Year & NTFP (Value in Lakh Rs.) & NTFP (Value in US\$) \\
\hline $2003-2004$ & 2151.64 & $2,872,683.57$ \\
$2004-2005$ & 1061.08 & $1,416,662.21$ \\
$2005-2006$ & 1002.42 & $1,338,344.45$ \\
$2006-2007$ & 1114.54 & $1,488,037.38$ \\
$2007-2008$ & 1029.00 & $1,373,831.77$ \\
$2008-2009$ & 959.28 & $1,280,747.66$ \\
$2009-2010$ & 658.99 & $879,826.43$ \\
$2010-2011$ & 1057.08 & $1,411,321.76$ \\
$2011-2012$ & 826.25 & $1,103,137.51$ \\
$2012-2013$ & 345.37 & $461,108.14$ \\
$2013-2014$ & 810.54 & $1,082,162.88$ \\
$2014-2015$ & 1058.83 & $1,413,658.21$ \\
$2015-2016$ & 335.50 & $447,930.57$ \\
$2016-2017$ & 129.20 & $172,496.66$ \\
$2017-2018$ & 226.50 & $302,403.20$ \\
$2018-2019$ & 186.68 & $249,238.98$ \\
\hline
\end{tabular}

${ }^{1}$ Source: Digest of Forest Statistics, 2017-2019. 
The annual market size of NTFP like Morchella esculenta, Trillium govanianum, Saussurea lappa and Aconitum heterophyllum was about US\$1.4 million, with less than 15\% share to primary collectors, whereas contractors and traders are reported to hold a huge chunk of margin [76]. Apparently, these contrasting estimates (of J\&K Forest Department and research findings) are only for a fraction of the species reported, which constitutes less than $10 \%$ of the products [32] actually extracted and traded in J\&K. Therefore, these estimations cannot be considered absolute due to the fragmented value chain and inadequate recognition of NTFP in the local economy leading to a lack of comprehensive information on the NTFP extracted, consumed, and traded from J\&K [75,76,91]. On the other hand, the carrying capacity of forests and the full market potential of NTFP sourced from the region have never been estimated [91] due to the unfavorable legal mechanism and discouraging governance framework [76].

The consolidation and demarcation of state forests of J\&K was initiated in 1891 [92] and under management plans in 1923. Since then, various forest legislations have been enacted primarily for the protection and management of forest products. We identified nine relevant forest legislations for examination and discussion.

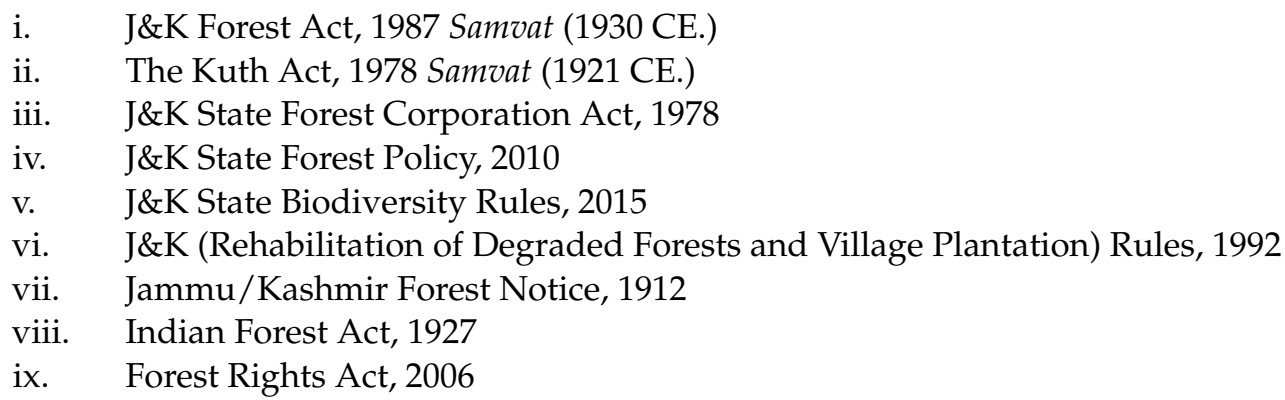

The demarcated forests of the state are legally owned by the government and managed through the Forest Department under the purview of J\&K Forest Act, 1987 Samvat (1930 CE). This Act initiated the timber-oriented commercial management of state forests in J\&K. Forest produce is considered an important source of revenue in this Act. Hence, the access of local communities to forests for the collection of such produce is restricted under this Act. Accordingly, the government has authority to regulate extraction and sale of forest produce in J\&K.

The Kuth Act, 1978 Samvat (1921 CE) was enacted for conservation, preservation, and protection of an important medicinal plant (Saussurea lappa CB Clarke) locally called Kuth and its produce in J\&K. The government of Maharaja (King) in $1921 \mathrm{CE}$ and subsequent governments had exclusive rights over the wild extraction, cultivation, trade, and export of the Kuth species. The Act prohibited the illicit cultivation, extraction, possession, transportation, export, and sale of Kuth plants or produce or any of its extracts and preparation. Violators of the Act were liable to be arrested without a warrant and punished with upto two years imprisonment or fined upto US\$68, or both. Later, J\&K Government extended the application of provisions of Kuth Act to other species, such as Artemisia maritima, Inula racemosa, Atropa acuminata, Aconitum heterophyllum, Lavatera kashmiriana, Dioscorea deltoidea, Colchicum luteum, Hyoscyamus niger, and Podophyllum emodi. However, due to the rapid decline in the quality and quantity of medicinal plants, the J\&K Government repealed this Act.

The Jammu and Kashmir State Forest Corporation (SFC) was established as a statutory body in pursuance of the J\&K State Forest Corporation Act, 1978 by converting the erstwhile Government Lumbering Undertaking. The main objective of the SFC is the harvesting and disposing of forest resources, particularly timber. However, currently, the activity of SFC is confined to removal of dead, dying, and diseased trees from the forests of J\&K with an annual extraction rate of $50,000 \mathrm{~m}^{3}$. The annual turnover of SFC was reported to be US\$8 million with a net profit of about US\$0.26 million [93].

The Government of J\&K formulated its first forest policy, the J\&K State Forest Policy, in 2010. The broad objectives of the policy are conservation of biodiversity and preservation 
of natural forests, rehabilitation of degraded forests, alleviating poverty, extension of tree cover outside forests, checking denudation and soil erosion, reducing pressure on forests, utilization of natural resources, development of non-timber forest produce, and institutionalization of eco-tourism and nature tourism. In particular, this policy provides for the management of NTFP:

(a) A package of practices for the cultivation of medicinal plants will be developed and farmers will be encouraged to undertake the cultivation of such medicinal plants and tree species on non-forest lands and private lands. Simultaneously, the handling, processing, transportation, and marketing of medicinal plants and related products will be facilitated.

(b) Value addition and processing of non-timber forest produce within the State will be encouraged along with development of market linkages and trade related information so that these are not exported in raw form, and producers get remunerative price for their produce.

(c) To facilitate conservation and development of medicinal plants in natural forests, including high- and low-level pasturelands, local communities will be encouraged to form co-operatives at village level for non-destructive harvesting, processing, and marketing of medicinal plants and other species having commercial value with a view to augmenting their income.

(d) Ladakh region of the state is a repository of many valuable medicinal plants. The cultivation of these herbs and shrubs in Ladakh will be taken up as apriority so that wild populations of these plants are not over-exploited to meet the ever-increasing demand.

(e) Resin tapping will be regulated in a sustainable manner ensuring that the chir crop, and its potential to regenerate, is not adversely affected.

(f) Laws, rules, and regulations will be revisited, reviewed, and rationalized to encourage activities referred to in the sub-paragraphs above.

The Government of J\&K notified the J\&K Biological Diversity Rules in 2015, in exercise of the powers conferred to it by Section 63 of the Biological Diversity Act, 2002. The Biological Diversity Act, 2002 has been enacted in India in pursuance of the United Nations Convention on Biological Diversity (CBD), 1992. The preamble to the Biological Diversity Act, 2002 borrows the objectives as laid down in the CBD and envisages to "provide for conservation of biological diversity, sustainable use of its components, and equitable sharing of benefits" arising from the biodiversity. The Act creates a three-tier structure of authorities to manage the biodiversity of India, namely the National Biodiversity Authority, State Biodiversity Boards, and Biodiversity Management Committees (BMCs). The BMCs have authority to prepare people's biodiversity registers and levy fees from any person for accessing or collecting any biological resources including NTFP for commercial purposes from areas within their territorial jurisdiction.

The state government established J\&K (Rehabilitation of Degraded Forests and Village Plantation) rules in 1992 for involving village communities in joint forest management. These rules provided the procedure of constitution and functioning of the village forest committee (VFC) in each forest range for joint management of forests by sharing responsibilities and benefits. The policy primarily stressed the participation of local people for the regeneration, maintenance, and protection of plantations for afforestation and rehabilitation of degraded forests and wastelands. It was envisaged that through local participation, the villagers would get access to NTFP, and share in timber revenues as a reward for their increased responsibility for forest protection. The VFC was entitled to $25 \%$ of the final harvest of the produce in kind or sale after deducting the costs incurred to raise such plantations. Benefits for village communities were later increased to $50 \%$ in the case of rehabilitation of degraded forests, and 75\% in the case of wastelands.

The Jammu Forest Notice and Kashmir Forest Notice of 1912 allow collection of NTFP that have not been auctioned by the J\&K Forest Department and those that are not 
exempted by any special orders of the government. Therefore, all other species which are not restricted by any special government order are free to be collected.

The Indian Forest Act, 1927, was extended to J\&K in 2020. The Act provides an overarching framework for forest management in India and seeks to consolidate the law relating to forests, the transit of forest produce, and the duty leviable on timber and other forest produce. The Act establishes three classes of forests, i.e., Reserve Forest, Protected Forest, and Village Forest. The Act defines "forest produce" as:

(a) timber, charcoal, caoutchouc, catechu, wood-oil, resin, natural varnish, bark, lac, kuth, myrobalans, dioscorea, firewood, humus, rasaunt, morels (Morchella spp), Aconitum spp., Podophyllum spp., Picrorhiza spp., Trillium spp., Nardostachys spp., Taxus spp., Valeriana spp., Rheum spp., wild animals, skins, tusks, horns, bones and all other parts or produce of wild animals whether found in or brought from a forests or not; and

(b) the following when found in, or brought from a forest, namely:

(i) trees and leaves, flowers and fruits, roots and all other parts or produce of trees not specified in clause (a);

(ii) plants not being trees (including grass, bamboos, creepers, reeds and moss and lichen), and all parts or produce of such plants;

(iii) silk, cocoons, honey and wax; and

(iv) peat, surface soil, rock and minerals (including limestone, laterite, mineral oils, and all products of mines or quarries);

As per the Act, NTFP are forest produce and species like Saussurea costus (Kuth), Terminalia spp. (Myrobalans), Dioscorea deltoidea (Dioscorea), Berberis aristata (Rasount), Morchella esculenta (Guchies), Aconitum heterophyllum (Patis/Atees), Picrorhiza kurrooa (Kour), Trillium govanianum (Nagchatri), Nardostachys jatamansi (Nordostachys), Taxus wallichiana (Taxus), Valeriana jatamansi (Valeriana), Rheum emodi (Rheum) are forest produce, irrespective of their origin (forest or non-forest area). The extraction of forest produce is an offence under the Act, unless allowed by the government. Further, the Act deals with the confiscation of illicit forest produce along with the tools and vehicles if any section of the Act is violated.

The Forest Rights Act, 2006 (FRA), which was enacted to ensure the protection of rights of the local indigenous communities in the rest of India, has recently been extended to J\&K. It is also known as the Scheduled Tribes and Other Traditional Forest Dwellers (Recognition of Forest Rights) Act, 2006. FRA recognizes the rights of the forest-dwelling local indigenous and other traditional communities to access forest resources for livelihood, habitation, and other sociocultural needs. The Act encompasses individual rights as selfcultivation and habitation and community rights, such as grazing, fishing, and accessing water bodies in forests, seasonal resource access of nomadic and pastoral communities, access to biodiversity, community rights to intellectual property and traditional knowledge, recognition of traditional customary rights, and right to protect, regenerate, or conserve or manage any community forest resource for sustainable use. The Act empowers the gram sabha (village council) to enable the influence of the local indigenous population in determining local policies and schemes impacting them. The Act provides for the right of ownership to access, use, and dispose of minor forest produce that has been traditionally collected within or outside village boundaries.

\subsection{Impact of Policy and Governance on NTFP Sector}

To ascertain the impacts of forest policy and governance on the NTFP sector, interviews were held with bellwethers (i.e., resource managers (forest officials), subject experts, primary collectors, traditional healers, and traders). The results of interviews with bellwethers revealed that the forest policies of J\&K have not fully embraced NTFP as a distinct category of forest products or area of management and therefore, have remained poorly understood and an increasingly marginalized part of forest management. Primary collectors, traditional healers, and traders have not been consulted or informed about government policies, legislation, or benefits of community participation in forest management. Most of the primary collectors were unaware of forest policies and legislation framework restricting 
the exploitation of forest products. Most of the people had not heard about the J\&K Forest Act, 1987 Samvat (1930 CE), or the Kuth Act, 1978 Samvat (1921 CE). About 14\% the people were aware of the J\&K State Forest Policy, 2010, but were skeptical about its implementation for the benefit of local communities. In addition, $8 \%$ of the bellwethers knew little about the policies yet believed that the policies and legislations were good in principle but ineffective in the field due to the top-to-down approach. Nearly $90 \%$ community members were unaware of the concessions as embodied in the Jammu/Kashmir Forest Notice, 1912 in lieu of obligatory assistance to the Forest Department. More than 60\% population is heavily dependent on forest resources for their day-to-day livelihood and income generation. Although few of their concessions and rights have been recognized in forest policies, their access is strictly restricted for any commercial purposes. Almost all of the primary collectors alleged that the people looting timber and NTFP from the forest areas do so with impunity from forest officials as well as other law enforcing agencies. They, however, are subjected to harsh punishments for even possessing a few kilograms of NTFP.

Almost all subject experts believed that NTFP are an important source of local livelihood and forest conservation. Hence, the forest policy should be more inclusive than restrictive. As many as 79\% experts interviewed believed that there is a need of NTFPspecific policy in J\&K. Moreover, $21 \%$ subject experts said that forest resource managers were not interested in promoting conservation and management of the products. Some experts believed that, if streamlined, the NTFP sector could have much higher economic potential than timber.

About $70 \%$ of traditional healers had some understanding of the regional forest legislations. They were aware of the fact that traditional healers have some concessions and are allowed to collect medicinal plants for personal use and to treat different ailments of the local people. Around a third believed that the regional forest legislation is complicated and are more authoritarian. Almost all traditional healers believed that the regional forest policies must be reviewed for the protection of the traditional rights and livelihood of the local communities.

All of the traders were confused about the forest policy and governance framework. Around $90 \%$ of them believed that NTFP are the only forest produce that have livelihood and employment potential as the green felling of forest trees is banned in J\&K, yet NTFP are the most restricted items for extraction and trade. Almost all traders had a correct understanding of the forest policies and legislation, and all traders believed that the policies are only for restriction of trade practices. All traders alleged that the redundant administrative obstacles in obtaining extraction and transportation permits from the Forest Department discourage traders in investing in the sector.

The majority $(80 \%)$ of the forest officials interviewed were aware of the J\&K Forest Act, 1987 Samvat (1930 CE), Kuth Act, 1978 Samvat (1921 CE) and the J\&K State Forest Policy, 2010. However, most did not know the objectives of these policies and legislations. The forest officials had no clear understanding about the role of NTFP in livelihood improvement and forest conservation as envisioned in the Forest Policy, 2010. The people interviewed believed that the Forest Policy has put more emphasis on protection of forests than development of NTFP for livelihood improvement. Accordingly, the rights and concessions of local communities with respect to NTFP are ambiguous and not clearly elaborated in the legislation.

\subsection{Potential of NTFP-Based Bioeconomy}

The information flow available on the volume of NTFP harvested, consumed, and traded from forests of J\&K is inadequate for policy makers. Recognizing the importance of NTFP and their integration into bioeconomy requires a systematic assessment at the regional level. For this study, selected NTFP have been considered for valuation in two different scenarios, namely the market price method and the maximum willingness to pay method, for showcasing their bioeconomy potential for the region. By using these 
methodologies, the revenues of the local communities were projected to increase upto 18 times the current price. The economic contributions of the selected NTFP were estimated at US\$ 2.3 million to the local economy of J\&K. With adoption of the bioresource vision of bioeconomy, the contributions may increase to US\$ 40.27 million (Table 4).

Table 4. Bioeconomy potential of selected NTFP sourced from the forests of Kashmir.

\begin{tabular}{|c|c|c|c|c|c|c|}
\hline \multirow[b]{2}{*}{ Species } & \multicolumn{3}{|c|}{ Present Contribution to State (US\$) } & \multicolumn{3}{|c|}{ Bioeconomy Potential (US\$) * } \\
\hline & $\begin{array}{c}\text { Quantity Traded } \\
\text { mt/yr (Dry } \\
\text { Weight) }\end{array}$ & $\begin{array}{c}\text { Local } \\
\text { Prices per } \\
\text { kg }\end{array}$ & $\begin{array}{l}\text { Contribution to } \\
\text { Local Economy }\end{array}$ & $\begin{array}{c}\text { Trade Potential } \\
\text { mt/yr (Dry } \\
\text { Weight) }\end{array}$ & $\begin{array}{l}\text { Maximum } \\
\text { Willingness to } \\
\text { Pay per kg }\end{array}$ & $\begin{array}{l}\text { Contribution to } \\
\text { Local Economy }\end{array}$ \\
\hline Acorus calamus Linn. & 60 & 0.53 & 31,800 & 700 & 1.06 & 742,000 \\
\hline $\begin{array}{l}\text { Aconitum heterophyllum } \\
\text { Wallich ex Royle }\end{array}$ & 10 & 26.70 & 267,000 & 100 & 80.10 & $8,010,000$ \\
\hline Angelica glauca Edgew & 10 & 2.00 & 20,000 & 100 & 10.68 & $1,068,000$ \\
\hline $\begin{array}{c}\text { Arnebia benthamii } \\
\text { (Wallich ex G.Don) } \\
\text { Johnston }\end{array}$ & 10 & 2.00 & 20,000 & 100 & 6.67 & 667,000 \\
\hline $\begin{array}{l}\text { Artemisia absinthium } \\
\text { Linn. }\end{array}$ & 35 & 1.00 & 35,000 & 500 & 2.67 & $1,335,000$ \\
\hline $\begin{array}{l}\text { Atropa acuminata Royle } \\
\text { ex. Lindl. }\end{array}$ & 25 & 1.06 & 26,500 & 200 & 4.00 & 800,000 \\
\hline Berberis lyceum Royle & 30 & 0.73 & 21,900 & 600 & 1.33 & 798,000 \\
\hline $\begin{array}{l}\text { Bergenia ciliata (Haw.) } \\
\text { Sternb. }\end{array}$ & 60 & 0.46 & 27,600 & 500 & 1.33 & 665,000 \\
\hline Digitalis lanata Ehrh. & 10 & 3.33 & 33,300 & 100 & 13.35 & $1,335,000$ \\
\hline Fritillaria roylei Hook. & 25 & 13.35 & 333,750 & 120 & 53.40 & $6,408,000$ \\
\hline Inula racemosa Hook. f. & 35 & 0.66 & 23,100 & 200 & 3.33 & 666,000 \\
\hline $\begin{array}{l}\text { Morchella esculenta } \\
\text { (Linn.) Pers. }\end{array}$ & 16 & 53.40 & 854,400 & 30 & 106.21 & $3,186,300$ \\
\hline $\begin{array}{l}\text { Picrorhiza kurrooa Royle } \\
\text { ex Benth. }\end{array}$ & 15 & 2.67 & 40,050 & 500 & 6.35 & $3,175,000$ \\
\hline $\begin{array}{l}\text { Podophyllum hexandrum } \\
\text { Royle }\end{array}$ & 25 & 1.33 & 33,250 & 100 & 3.00 & 300,000 \\
\hline Phytolacca acinosa Roxb. & 10 & 1.33 & 13,300 & 120 & 3.00 & 360,000 \\
\hline $\begin{array}{l}\text { Saussurea costus (Falc.) } \\
\text { Lipsch. }\end{array}$ & 45 & 1.33 & 59,850 & 200 & 3.35 & 670,000 \\
\hline Thymus linearis Benth. & 10 & 1.33 & 13,300 & 100 & 4.00 & 400,000 \\
\hline Tribulus terrestris Linn. & 10 & 0.46 & 4,600 & 300 & 1.33 & 399,000 \\
\hline $\begin{array}{c}\text { Trillium govanianum } \\
\text { (Wall. Ex D.Don.) } \\
\text { Kunth }\end{array}$ & 40 & 10.68 & 427,200 & 150 & 53.40 & $8,010,000$ \\
\hline Valeriana jatamansi Jones & 30 & 2.27 & 68,100 & 700 & 5.34 & $3,738,000$ \\
\hline Total US\$ & 511 & - & $2,354,000$ & 5420 & - & $42,732,300$ \\
\hline
\end{tabular}

\section{Discussion}

There are no specific policies at the regional or national level regarding the sustainable management of NTFP and livelihood improvement. Regional forest policy lacks a clear definition of NTFP, their governance, and objectives for holistic development of NTFP. The forest management and policy of J\&K have focused primarily on protection of forests for timber with no recognition of the roles of NTFP in poverty alleviation, forest conservation, and revenue generation. Emphasis on timber, while neglecting NTFP, has encouraged the overexploitation of resources, leading to the fragmentation and degradation of state forests and diminishing the livelihood options of forest-dependent communities. The reduction in 
the productivity and diversity of the state forests illustrate the inadequacy of policies and management frameworks, and the disconnect from necessities and demands of the region.

The Government of J\&K shows little recognition for the rights of local people over the forests and forest produce. However, village communities living near forests have some concessions for domestic use, as embodied in Jammu/Kashmir Forest Notice. Unfortunately, restrictions on the extraction of certain forest products have created concerns about the ban on cultivation of the species. Notionally, there is no ban on cultivation, yet farmers have to get a "no objection certificate" to cultivate, as well as a permit to transport harvested produce. However, most primary producers interviewed knew nothing about such procedures, and for them there is a ban on cultivation of medicinal plants.

The Forest Department may be hesitant to allow cultivation of medicinal plants on farmlands, as there is no policy or management mechanism to track and monitor production. There is no way for the Department to determine if the produce was cultivated or illegally extracted from forests. The absence of clear policy or instructions has created ambiguity at the divisional level, whether to issue permits or not for the cultivation of medicinal plants. More frustrating, the medicinal plants certification scheme of the National Medicinal Plants Board and the Quality Council of India does little to address this issue. The certification mechanism is concerned only about quality control of the raw material and not the legality of its origin. Therefore, the perceived ban on cultivation of medicinal plants has restricted the NTFP sector in J\&K.

The poor recognition and inadequate development of NTFP sector in J\&K is also due to the lack of an appropriate institutional and governance framework. The limited institutional models, lack of application of scientific and operational knowledge, and local level demonstration on the management of NTFP inhibit development of the sector. The forest management in the region has focused on access, control, tenure, and institutional issues. There is no credible information available on the growing stock of NTFP, extraction potential of economically important species and their sustainable harvesting limits, valuation of these resources, people's dependency, and contribution of these resources to the rural and state economy.

Local communities are hampered by poor governance, which requires substantial shift in policy to adequately include the local communities and improve resources for the local economy. Transitioning to NTFP-based bioeconomy offers opportunities for improving local livelihoods, revenue generation, addressing conservation issues and related tradeoffs. However, to operationalize this concept, policy and governance implications based on improving access and benefit sharing and related institutional models are imperative. Fostering public-community partnerships by modifying the restrictive roles of contractors from NTFP value chains is recommended. Results indicate that local government could increase revenues upto 18 -fold by adopting bioeconomy principles.

Drawing on learnings from experiences of other Indian states (e.g., Madhya Pradesh and Chhattisgarh) the minimum support price (MSP) mechanism may be more suitable for the local context [94]. Under the MSP mechanism, local indigenous communities can sell wild-harvested or cultivated NTFP to the government/Forest Department/cooperatives at a mutually agreed fixed price, avoiding intermediaries. The government departments procure raw material at a fixed price, trade with industries after some value addition or processing, and share profits with collectors and growers. This mechanism addresses the issue of storage infrastructure, provides opportunities for grading, value addition, and better price points, and improves livelihood potential. Therefore, the adoption of such policies and governance would support the transition to an NTFP-based bioeconomy.

\subsection{Policy and Governance Implications for Transition to NTFP-Based Sustainable Bioeconomy}

With increasing awareness, policymakers are focusing more on bio-based products sourced from forests [95]. This, in part, is driving interest in sustainable management and harvesting of NTFP, commercial cultivation, and diversification of value chains to model transition towards an inclusive and sustainable bioeconomy. Adopting contemporary 
visions of bioeconomy, will take policies and governance that advance value addition at the primary producer and processor level, and then advance the value chain. However, this concept needs to penetrate to the sub-national levels, where the actual actions take place, to coordinate and accelerate the growth to realize its full potential [65].

Review of earlier sub-national level governance models (e.g., Andhra Pradesh, Chhattisgarh, Madhya Pradesh) showcase the possibilities of NTFP-based benefit-sharing mechanism. For example, the Vindhya Valley brand owned and developed by the Madhya Pradesh Forest Department has streamlined collection process and created value for NTFP at the primary collector level through the formation of state cooperatives [96]. These models can be modified to take advantage of the global demand for temperate forest products, and the traditions of indigenous knowledge of NTFP in J\&K. Furthermore, the trade volume from India is increasing in the global herbal medicine industry [97], although it is far from transparent, with few mechanisms to ensure fair trade practices. Public investment would improve transparency and data management. Further, the enforcement of economic instruments like harvesting quotas and increased cultivation in non-forest areas could benefit the communities. Policy and governance mechanisms may emulate such a framework for the transition to an NTFP-based bioeconomy (Figure 3).

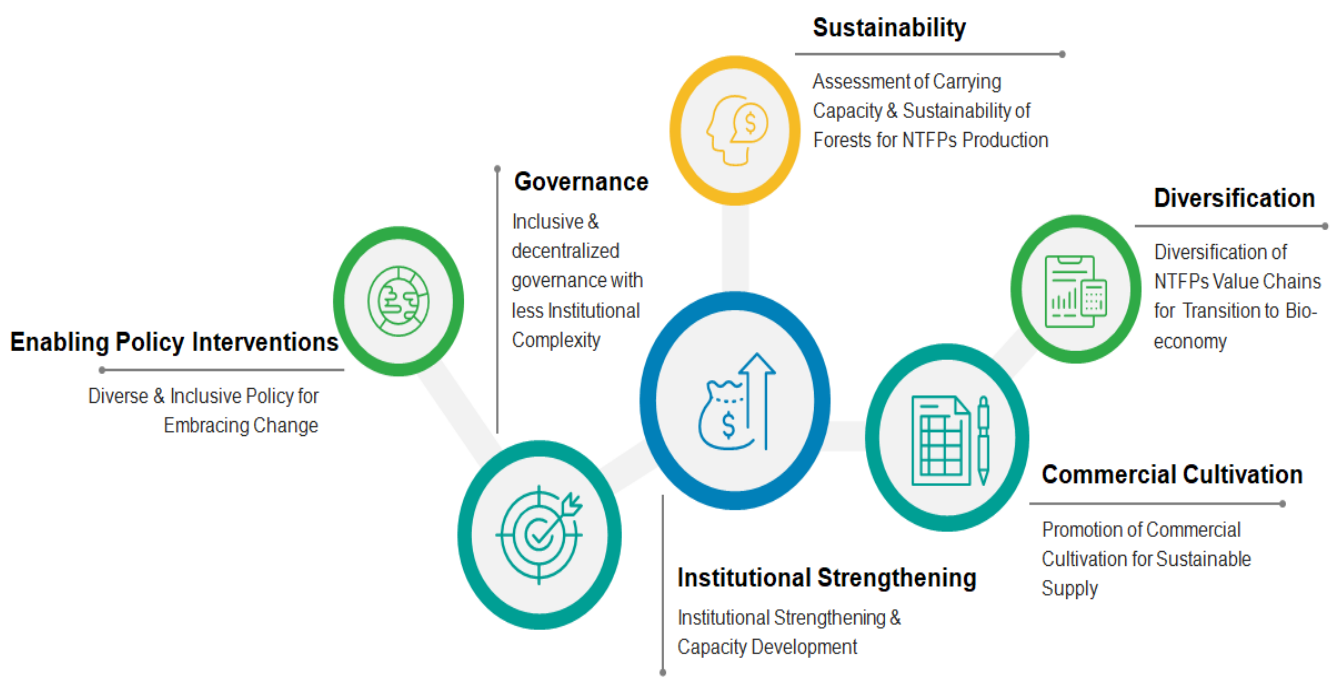

Figure 3. Policy and governance implications for transition to NTFP-based bioeconomy. Source: Conceptualized and developed by Authors.

\subsubsection{Enabling Policy Interventions}

Forest policies must be revised to embrace NTFP for rural development, poverty alleviation, and income generation. A diverse and inclusive NTFP-specific policy is obligatory. Policies must reduce regulatory hurdles and encourage local producers support, as well as be aligned with the country's development goals. The diverse contributions of NTFP must be acknowledged in regional and national accounts with amplified investments in the sector. State forest management plans need significantly more information on the availability, distribution, growing stock, identification keys, and conservation plans for development of the NTFP-sector. Information on the carrying capacity of the forests as well as species harvesting potential, limits, and extent of people's dependency on these resources must be documented.

Moreover, balanced production from natural populations and on farms is needed. The sustainable harvesting of the annual species and products (e.g., Morchella esculenta) should be allowed from forests of the region. Periodical harvesting of species (e.g., Saussurea costus, Aconitum heterophyllum, Picrorhiza kurrooa, Trillium govanianum, Valeriana jatamansi, Rheum emodi) should be considered with the determination of impacts. Further, sustainable harvesting of species (e.g., Arnebia benthamii, Artemisia absinthium, Digitalis purpurea, Ephedra 
gerardiana, Viola odorata, Achillea millefolium, Berberis lyceum, and Thymus linearis) exploited for aerial parts, like fruits, flowers, and leaves, should be allowed on a rotational basis, with due attention to their regenerative capacity.

\subsubsection{Inclusive and Decentralized Governance Mechanism}

Governance for NTFP is characterized by institutional complexity due to intricate connections between sustainability, access to resources and markets, and benefit-sharing provisions. Successful governance institutions, such as a dedicated state level authority or cooperative for the procurement standardization, value addition, processing, and trade with the help of local institutions like VFCs or BMCs can address many underplaying issues. Participatory management and conservation of the resources would help in conflict resolution. Local community institutions at the forest level may be empowered for NTFP production and sustainable harvesting. Further, the consolidation of harvests and postharvest management, as well as value addition of the produce may be done at the local level. Processing, value chain diversification, product development, and marketing may be carried out at a regional or state level. Such governance mechanisms can address resource sustainability, livelihoods, and revenue generation. Inclusive models are available in other Indian states (e.g., Madhya Pradesh, Chhattisgarh, Odisha), where government cooperative systems have been created for the extraction, management, and trade of NTFP.

The state should empower a nodal authority to consolidate, integrate, and monitor all NTFP activities in J\&K. The governance mechanism will require necessary financial resource allocations from the government to bring in the desired changes. Therefore, an efficient governance structure (Figure 4) consisting of local community institutions, relevant ministries, departments, and farm universities must be strengthened for a more inclusive, transparent, accountable, and robust delivery system for the transition to an NTFP-based bioeconomy in J\&K.

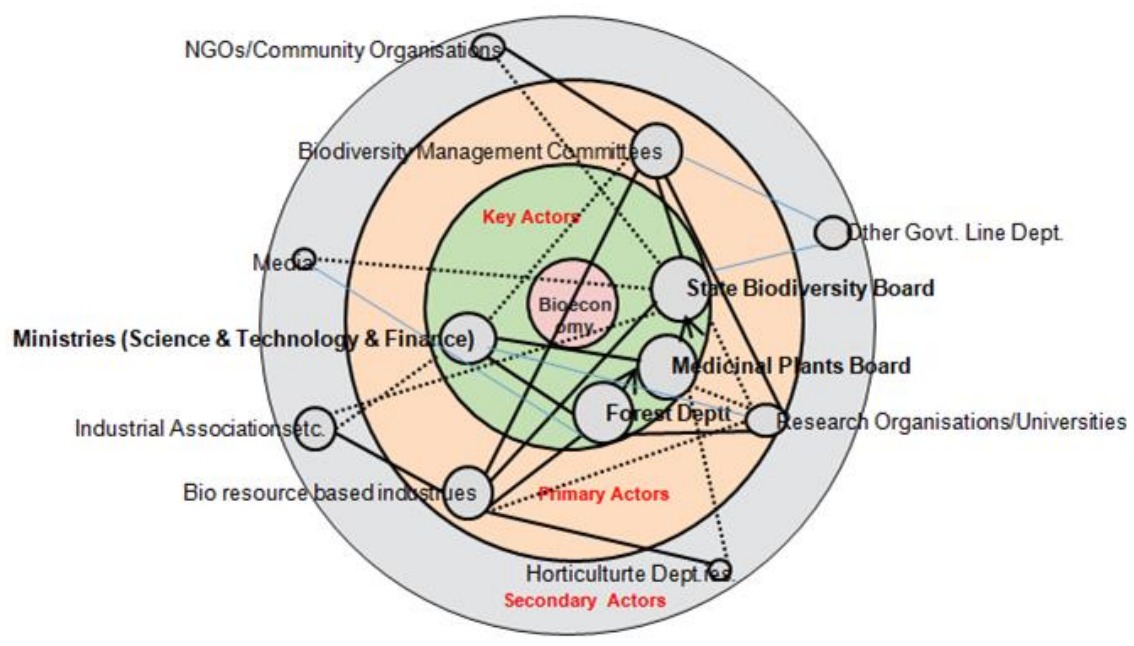

Figure 4. Governance structure for transition to NTFP-based Bioeconomy in J\&K. Source: Conceptualized and developed by Authors.

\subsubsection{Institutional Strengthening and Capacity Development}

Transition to a bioeconomy requires building capacity of policy makers and resource managers to guide the process. This study revealed that there is the need for capacity building at various levels, including frontline staff of the Forest Department and local community institutions for the sustainable development and management of NTFP with the help of academic institutions and NGOs. Strengthening local institutions and capacity development is significant for the transition to an NTFP-based bioeconomy. Due to various geopolitical issues, J\&K has not benefited from technical assistance programs of the central government. 


\subsubsection{Assessment of Carrying Capacity and Sustainability of Forests for NTFP Production}

There is need for comprehensive assessments of carrying capacity and the sustainability of forests for NTFP production. Assessments through spatial and onsite scientific investigations provide data about the availability, distribution, diversity, and sustainability of resources. A database of such information would be a key tool in designing and developing programs. The identification of resource-rich areas and their sustainability status would facilitate diversification of livelihoods, through participation in planning for resource conservation, augmentation, and commercial exploitation. Management plans need to address medicinal plant resource base, regeneration potential, and areas suitable for the in-situ conservation and cultivation. The focus of planning should be expanded to include NTFP management. Overall, advanced technologies for resource planning and trade monitoring will improve transparency.

\subsubsection{Promotion of Commercial Cultivation for Sustainable Supply}

Diversified NTFP production within forests and on farms is essential. However, production within forests is usually preferred for high altitude medicinal plants, as there are serious apprehensions about variations in the biochemical compounds of wild and cultivated species [98]. The climatic, edaphic, topographic, and biotic factors, including the associated biodiversity, have a distinct role in the accumulation of biochemical compounds of plant species. Hence, the Forest Department would be wise to demarcate medicinal plants production areas (MPDAs) for in-forest production. Such a strategy would help in species restoration, as well as the generation of income and employment.

Out of forest production, particularly in agroforestry systems, is important for the conservation of species. The choice of species depends on socioeconomic factors, ecogeographic considerations, and species regeneration capacity. The cultivation of NTFP would enhance forest-based livelihoods through higher yields, uniform harvests, and stable price and markets. It would augment the natural resource base, reduce pressure on forests, and help in conservation of endangered species. Forest fringe communities may be motivated through incentives and training on good agricultural practices, sustainable harvesting, value addition, and marketing of NTFP. Policies should be supported with NTFP management practices to realize their full potential. Awareness creation on the sustainable development and management of NTFP must be initiated to promote their cultivation on a large scale.

\subsubsection{Diversification of NTFP Value Chains for Transition to Bioeconomy}

There is great scope for value chain diversification to realize the bioeconomy potential of NTFP. So far, only a few medicinal plants have been exploited and are being supplied as raw material only. The renewed demand in the pharmaceutical, nutraceutical, cosmetic, food, beverage, and agro-industries for novel bioactive compounds may present opportunities for transition to a bioeconomy. For example, Acorus calamus, which was largely exploited for its medicinal and aromatic properties, is now in high demand for its use as a biological pest-control [99]. Similarly, Phytolacca acinosa, another medicinal plant, is now sought-after for a dye used in solar panels [100]. Another medicinal plant, Angelica glauca, is being used as a flavoring agent in wines and confectionery items [101]. Clearly, NTFP resources of the region have tremendous potential for supporting a bioeconomy, provided the appropriate policy, governance framework, and value chain are embraced.

\section{Conclusions}

The significance of NTFP is well documented and the sector has a great potential to uplift rural and urban economies if managed sustainably. NTFP are being integrated into innovative conservation and developmental strategies, including bioeconomy, provided policy and governance barriers are addressed. The J\&K Government has pursued management of forests and implementation of forest policies in the region. However, policies are needed that fully incorporate NTFP for revenue generation and livelihood improvement 
of forest fringe communities. It is, therefore, important to have appropriate policy and management frameworks for the holistic development of the NTFP-sector and its transition to a bioeconomy. The bioresource vision of bioeconomy provides an opportunity for the diversification of biological raw materials like non-timber forest products with an emphasis on processing, upgrading, and establishing new value chains with the changing demands of customers and market requirements. It is important that policy and governance barriers are removed, and the actual values of NTFP are realized instead of a notional value. Moreover, to operationalize this concept, inclusive, transparent, and equitable policies and governance mechanisms are required to guide the transition to a sustainable bioeconomy. Implications of this study to improve the transition to a bioeconomy support inclusive and interactive governance, the strengthening of institutions, sustainable management of resources, diversification of value chains, and the promotion of cultivation.

Author Contributions: Conceptualization, I.A.P. and M.R.; methodology, I.A.P. and M.R.; investigation, I.A.P. and M.R.; data collection and interviewing, I.A.P.; writing-original draft preparations I.A.P. and M.R.; commenting, reviewing, suggesting on improvement, J.C., S.D., M.R. and S.S.; revising and editing J.C., S.D., S.S., M.R. and I.A.P.; visualization and formatting, I.A.P., J.C. and S.S.; supervision and project administration, I.A.P. All authors have read and agreed to the published version of the manuscript.

Funding: The first author gratefully acknowledges the support received for part of this study from Scientific \& Engineering Research Board, Government of India through its prestigious "Young Scientist Scheme" project ID SR/FT/LS-55/2012.

Institutional Review Board Statement: Not applicable.

Informed Consent Statement: Not applicable.

Data Availability Statement: The data presented in this study are available on request from the corresponding author. The data are not publicly available due to issues of respondent confidentiality and conditions of ethical approval.

Acknowledgments: The authors are grateful to officials of the J\&K Forest Department, local community members and traders for sharing their views during various discussions held on the topic with them.

Conflicts of Interest: The authors declare no conflict of interest.

\section{References}

1. FAO. Non Wood Forest Products for Rural Income and Sustainable Forestry; NWFPs 7; FAO: Rome, Italy, 1995. Available online: http:/ / www.mekonginfo.org/assets/midocs/0001410-environment-non-wood-forest-products-for-rural-income-andsustainable-forestry.pdf (accessed on 12 July 2020).

2. Arnold, J.E.M.; Ruiz-Pérez, M. Can non-timber forest products match tropical conservation and development objectives? Ecol. Econ. 2001, 39, 437-447. [CrossRef]

3. Iponga, D.M.; Mikolo, Y.C.; Lescuyer, G.; Assoumou, F.M.; Levang, P.; Tieguhong, J.C.; Ngoye, A. The contribution of NTFP gathering to rural people's livelihoods around two timber concessions in Gabon. Agrofor. Syst. 2018, 92, 157-168. [CrossRef]

4. Babulo, B.; Muys, B.; Nega, F.; Tollens, E.; Nyssen, J.; Deckers, J.; Mathijs, E. The economic contribution of forest resource use to rural livelihoods in Tigray, Northern Ethiopia. For. Policy Econ. 2009, 11, 109-117. [CrossRef]

5. Asfaw, A.; Lemenih, M.; Kassa, H.; Ewnetu, Z. Importance, determinants and gender dimensions of forest income in Eastern highlands of Ethiopia: The case of communities around JeloAfromontane forest. For. Policy Econ. 2013, 28, 1-7. [CrossRef]

6. Sacande, M.; Parfondry, M. Non-Timber Forest Products: From Restoration to Income Generation; FAO: Rome, Italy, 2018. Available online: http:/ / www.fao.org/3/CA2428EN/ca2428en.pdf (accessed on 12 July 2020).

7. Heubach, K.; Wittig, R.; Nuppenau, E.A.; Hahn, K. The economic importance of non-timber forest products (NTFPs) for livelihood maintenance of rural west African communities: A case study from northern Benin. Ecol. Econ. 2011, 70, 1991-2001. [CrossRef]

8. Ahenkan, A.; Boon, E. Commercialization of non-timber forest products in Ghana: Processing, packaging and marketing. Food Agric. Environ. 2010, 8, 962-969.

9. FAO. Can Non-Wood FOREST Products Help Contribute to Achieving the Millennium Development Goals? FAO: Rome, Italy, 2006. Available online: http:/ / www.fao.org/forestry/12372-0383f18194064147d3b13e2979072fc28.pdf (accessed on 12 July 2020).

10. de Beer, J. On Forest Foods, a Festival and Community Empowerment. CFA NewsLett. 2011, 54, 1-5.

11. Peerzada, I.A.; Sofi, A. Traditional use of medicinal plants among tribal communities of Bangus Valley, Kashmir Himalaya, India. Stud. Ethno-Med. 2017, 11, 318-331. 
12. Arnold, J.E.M.; Ruiz-Perez, M. The role of non-timber forest products in conservation and development. In Incomes from the Forest: Methods for the Development and Conservation of Forest Products for Local Communities; Wollenberg, E., Ingles, A., Eds.; CIFOR/IUCN: Bogor, Indonesia, 1998; pp. 17-42. Available online: https://www.cifor.org/knowledge/publication/479 (accessed on 12 July 2020).

13. Golam, R.; Madhav, K.; Ram, P.S. The role of non-timber forest products in poverty reduction in India: Prospects and problems. Dev. Pract. 2008, 6, 779-788.

14. Choudhury, P.R. Forest-Route to Poverty Alleviation-Myths and Realities: Analysis of NTFPs-Livelihood Linkages in Some Indian States. In Proceedings of the RRI Conference, Bangkok, Thailand, 4-7 September 2007. Available online: https://www.researchgate.net/publication/280714046_Forest-Route_to_Poverty_Alleviation-Myths_and_Realities_Analysis_ of_NTFP-Livelihood_Linkages_In_Some_Indian_States (accessed on 12 July 2020).

15. FAO. An Information Bulletin on Non-Wood Forest Products. Non-Wood News; FAO: Rome, Italy, 2008; Volume 17, pp. 12-21. Available online: http:/ / www.fao.org/3/i0235e/i0235e00.htm (accessed on 12 July 2020).

16. Wiersum, K.F. From natural forest to tree crops, co-domestication of forests and tree species, an overview. Neth. J. Agric. Sci. 1997, $45,425-438$.

17. Gómez-Baggethun, E.; Corbera, E.; Reyes-García, V. Traditional ecological knowledge and global environmental change: Research findings and policy implications. Ecol. Soc. 2013, 18, 72. [CrossRef] [PubMed]

18. Shackleton, C.; Shackleton, S. The importance of non-timber forest products in rural livelihood security and as safety nets: A review of evidence from South Africa. S. Afr. J. Sci. 2004, 100, 658-664.

19. Maxted, N.; Kella, S.; Ford-Lloyda, B.; Ehsan, D.; Álvaro, T. Toward the systematic conservation of global crop wild relative diversity. Crop Sci. 2012, 52, 774-785. [CrossRef]

20. Vincenta, H.; Wiersemab, J.; Kella, S.; Fielder, H.; Dobbie, S.; Castañeda-Álvarez, N.P.; Guarino, L.; Eastwood, R.; León, B.; Maxted, N. A prioritized crop wild relative inventory to help underpin global food security. Biol. Conserv. 2013, 167, 265-275. [CrossRef]

21. Marshall, E.; Schreckenberg, K.; Newton, A. Commercialization of non-timber forest products: First steps in analyzing the factors influencing success. Int. For. Rev. 2003, 2, 128-137.

22. Ahenkan, A.; Boon, E. Non-timber forest products farming and empowerment of rural women in Ghana. Environ. Dev. Sustain. 2011, 13, 863-878. [CrossRef]

23. Sunderland, T.; Ndoye, O. Forest Products, Livelihoods and Conservation. Case Studies of Non-Timber Forest Products Systems, Africa; CIFOR: Bogor, Indonesia, 2004; Volume 2, pp. 1-55. Available online: https://www/cifor.org/publications/pdf_files/Books / NTFPAfrica/TOC-Chapter6.PDF (accessed on 12 July 2020).

24. Shanley, P.; Alan, R.P.; Laird, S.A.; Citlalli, L.B.; Manuel, R.G. From Lifelines to Livelihoods: Non-timber Forest Products into the Twenty-First Century. In Tropical Forestry Handbook; Pancel, L., Köhl, M., Eds.; Springer: Berlin/Heidelberg, Germany, 2015. [CrossRef]

25. FAO. Assessing the Contribution of Bioeconomy to Countries' Economy: A Brief Review of National Frameworks; Food and Agriculture Organization of United Nations: Rome, Italy, 2018; p. 67. Available online: http://www.fao.org/3/I9580EN/i9580en.pdf (accessed on 12 July 2020).

26. MEA. Ecosystem and Human Well-being: A Framework for Assessment, Millennium Ecosystem Assessment Series; Island Press: Washington, DC, USA, 2003; Available online: https:/ / pdf.wri.org/ecosystems_human_wellbeing.pdf (accessed on 12 July 2020).

27. Ingram, V.; Ndoye, O.; Iponga, D.; Tieguhong, J.C.; Nasi, R. Non-Timber Forest Products: Contribution to National Economy and Strategies for Sustainable Management. In The Forests of the Congo Basin-State of the Forest 2010; de Wasseige, C., de Marcken, P., Bayol, N., Hiol Hiol, F., Mayaux, P., Desclée, B., Nasi, R., Billand, A., Defourny, P., Eba'a, R., Eds.; Publications Office of the European Union: Luxembourg, 2012; pp. 137-154.

28. Muir, G.; Simona, S. Making NWFPS Visible: Disentangling Definitions and Refining Methodologies. In Proceedings of the HQ. Agenda Item 10.2: Overview of Forestry and Environment Statistics in AP Region, 27th Session, Port Denarau, Fiji, 19-23 March 2018.

29. Goraya, G.S.; Ved, D.K. Medicinal Plants in India: An Assessment of Their Demand and Supply; National Medicinal Plants Board, Ministry of AYUSH, Government of India, New Delhi and Indian Council of Forestry Research \& Education: Dehradun, India, 2017.

30. Shivaprasad, T.M.; Chandrashekar, H.M. Impact of New Forest policies on Collection and Marketing of Minor Forest Produce in Karnataka, with Special reference to LAMPS. IOSR J. Human Soc. Sci. 2014, 19, 9-14.

31. Laird, S.A.; Awung, G.L.; Lysinge, R.J.; Ndive, E.L. The interweave of people and place: Biocultural diversity in migrant and indigenous livelihoods around Mount Cameroon. Int. For. Rev. 2011, 13, 275-293. [CrossRef]

32. Peerzada, I.A. Development of NTFPs and Livelihood of Rural Communities in Temperate Forests of Kashmir Valley, India; A Project Completion Report (No. SR/FT/LS-55/2012) Submitted to Scientific \& Engineering Research Board; Government of India: New Delhi, India, 2016.

33. Haripriya, G.S. Integrated environmental and economic accounting: An application to the forest resources in India. Environ. Res. Econ. 2001, 19, 73-95. [CrossRef]

34. Shanley, P.; Pierce, A.; Laird, S.; Guille'n, A. Tapping the Green Market: Certification and Management of Non-Timber Forest Products; Earthscan: London, UK, 2002. Available online: https://www.researchgate.net/publication/272743208_Tapping_the_Green_ Market_Certification_and_Management_of_Non-timber_Forest_Products (accessed on 12 July 2020). 
35. Ahenkan, A.; Boon, E. Enhancing Food Security, Poverty Reduction and Sustainable Forest Management in Ghana through NonTimber Forest Products Farming: Case Study of Sefwi Wiawso District. 2008. Available online: www.grin.com/de/preview/.html (accessed on 12 July 2020).

36. Mbuvi, D.; Boon, E. The livelihood potential of nonwood forest products: The case of Mbooni Division in Makueni District, Kenya. Environ. Dev. Sustain. 2008, 11, 989-1004. [CrossRef]

37. Bennett, B.C. Plants and people of the Amazonian rainforests. BioScience 1992, 42, 599-607. [CrossRef]

38. Cocks, M.L.; Dold, A.P. A new broom sweeps clean: The economic and cultural value of grass brooms in Eastern Cape Province, South Africa. For. Trees Livelihoods 2004, 13, 33-42. [CrossRef]

39. Schreckenberg, K.; Awono, A.; Degrande, A.; Mbosso, C.; Ndoye, O.; Tchoundjeu, Z. What do non-timber products mean for forest conservation? IUCN Bullet. 2006, 3, 13-15.

40. Wynberg, R.; Van-Niekerk, J.; Kozanayi, W.; Laird, S. Formalisation and the Non-Timber Forest Product Sector: Experiences from Southern Africa; Report; CIFOR: Bogor, Indonesia, 2012; Available online: https: / www1.cifor.org/fileadmin/subsites / proformal/ PDF/RWynberg1207.pdf (accessed on 12 July 2020).

41. Shackleton, C.M.; Pandey, A.K. Positioning non-timber forest products on the development agenda. For. Policy Econ. 2014, 38, 1-7. [CrossRef]

42. Ruiz-Perez, M.; Byron, N. A methodology to analyze divergent case studies of Non-Timber Forest Products and their development potential. For. Sci. 1999, 45, 1-14.

43. TEEB. The Economics of Ecosystems and Biodiversity: Mainstreaming the Economics of Nature: A Synthesis of the Approach, Conclusions and Recommendations of TEEB; UNEP: Nairobi, Kenya, 2010. Available online: http:/ /www.teebweb.org/wp-content/uploads/ Study\%20and\%20Reports/Reports/Synthesis\%20report/TEEB\%20Synthesis\%20Report\%202010.pdf (accessed on 12 July 2020).

44. de-Arano, I.M.; Feliciano, D.; Rigolot, E.; Lefevre, F.; Prokofieva, I.; Labidi, J.; Carnus, J.M.; Secco, L.; Fragiacomo, M.; Follesa, M.; et al. A Forest-Based Circular Bioeconomy for Southern Europe: Visions, Opportunities and Challenges. 2018, p. 124. Available online: https:/ / hal.inrae.fr/hal-02790145/document (accessed on 2 December 2020).

45. Tikkanen, J.; Takala, T.; Marja-Liisa, J.; Kurttila, M.; Vanhanen, H. Challenges and Solutions for Non-Timber Forest Product Businesses in Finland-An Application of the SODA Analysis. Forests 2020, 11, 753. [CrossRef]

46. Laird, S.A.; Wynberg, R. Diversity and change in the commercial use of genetic resources: Implications for access and benefit sharing policy. Int. J. Ecol. Econ. Stat. 2012, 26, 2-15.

47. Saxena, N. Livelihood Diversification and Non-Timber Forest Products in Orissa: Wider Lessons on the Scope for Policy Change? Working Paper 223; Overseas Development Institute: London, UK, 2003. Available online: https://www.files.ethz.ch/isn/95710/wp223 .pdf (accessed on 12 July 2020).

48. Andel, T.R. Non-Timber Forest Products of the North-West District of Guyana Part II, a Field Guide. Available online: https:/ / www.researchgate.net/publication/27686003_Non-timber_forest_products_of_the_North-West_District_of_Guyana\# fullTextFileContent (accessed on 12 July 2020).

49. Shiva, M.P.; Verma, S.K. Approaches to Sustainable Forest Management and Biodiversity Conservation: With Pivotal Role of Non-Timber Forest Products; Centre for Minor Forest Products, Valley Offset Printers: Dehra Dun, India, 2002.

50. Maffi, L.; Woodley, E. Biocultural Diversity Conservation: A Global Sourcebook; Routledge: London, UK, 2012.

51. Laird, S.A. Bioscience at a Crossroads: Access and Benefit Sharing in a Time of Scientific, Technological and Industry Change: The Pharmaceutical Industry; Secretariat of the Convention on Biological Diversity: Montreal, QC, Canada, 2013. Available online: https:/ / www.cbd.int/abs/policy-brief/default.shtml/ (accessed on 12 July 2020).

52. Newman, D.J.; Cragg, G.M. Natural products as sources of new drugs over the last 30 years from 1981 to 2010. J. Nat. Prod. 2012, 75, 311-335. [CrossRef] [PubMed]

53. Díaz, S.; Fargione, J.; Chapin, F.S.; Tilman, D. Biodiversity Loss Threatens Human Well-Being. PLoS Biol. 2006, 4, e277. [CrossRef]

54. Roos, A. Business-Bioproducts in the Bioeconomy. In Environmental Impacts of Traditional and Innovative Forest-Based Bioproducts; Kutnar, A., Muthu, S.S., Eds.; Springer: Berlin/Heidelberg, Germany, 2016.

55. Henry, G.; Trigo, E.J. The Knowledge Based Bio-Economy at Work: From Large Scale Experiences to Instruments for Rural and Local Development. Available online: https://agritrop.cirad.fr/557872/ (accessed on 12 July 2020).

56. Linser, S.; Lier, M. The contribution of sustainable development goals and forest-related indicators to national bioeconomy progress monitoring. Sustainability 2020, 12, 2898. [CrossRef]

57. Piplani, M. A Global Bioeconomy Framework with Forest-Based Schools: Theory and Its Application to Primary Products in Nepal and Finland, SuTroFor-GEEFT. Master's Thesis, AgroParisTech, Centre de Montpellier, Montpellier, France, 2021.

58. FAO. State of the WORLD'S Forests: Enhancing the Socioeconomic Benefits from Forests. 2014. Available online: http://www. fao.org/3/a-i3710e.pdf (accessed on 12 July 2020).

59. Carus, M.; Carrez, D.; Kaeb, H.; Ravenstijn, J.; Venus, J. Level Laying Field for Bio-Based Chemistry and Materials. 2011. Available online: http:/ / bio-based.eu/nova-papers/ (accessed on 12 July 2020).

60. Nicolas, M. Big data in the forest bioeconomy: The good, the bad, and the ugly. J. Sci. Technol. Prod. Process. 2020, 5, 6-15.

61. Hurmekoski, E.; Jonsson, R.; Korhonen, J.; Jänis, J.; Mäkinen, M.; Leskinen, P.; Hetemäki, L. Diversification of the Forest Industries: Role of New Wood-Based Products. Can. J. For. Res. 2018, 48, 1417-1432. [CrossRef] 
62. Hetemäki, L.; Palahi, M.; Nasi, R. Seeing the Wood in the Forests. Knowledge to Action 01; European Forest Institute (EFI): Joensuu, Finland, 2020; Volume 17. Available online: https:/ / efi.int/publications-bank/seeing-wood-forests (accessed on 2 December 2020).

63. Biancolillo, I.; Paletto, A.; Bersier, J.; Keller, M.; Romagnoli, M. A literature review on forest bioeconomy with a bibliometric network analysis. J. For. Sci. 2020, 66, 265-279.

64. DBT. National Biotechnology Development Strategy; Department of Biotechnology, Ministry of Science and Technology, Government of India: New Delhi, India, 2015; 44p. Available online: https:/ / dbtindia.gov.in/sites/default/files/DBT_Book-_29-december_20 15.pdf (accessed on 12 July 2020).

65. Anonymous. Accelerating Growth: Forging India's Bioeconomy; Biotechnology Industry Organization (BIO) and the Association of Biotechnology Led Enterprises (ABLE): New Delhi, India, 2014. Available online: https://www.bio.org/sites/default/files/ legacy/bioorg/docs/files/Burrill_AcceleratingGrowth_India-6-9-final.pdf (accessed on 12 July 2020).

66. Anonymous. India Bioeconomy Report; Association of Biotechnology Led Enterprises (ABLE), Biotechnology Industry Research Assistance Council (BIRAC): New Delhi, India, 2019. Available online: https://www.birac.nic.in/webcontent/1579089535_India_ BioEconomy_Report_2019.pdf (accessed on 12 July 2020).

67. Kitchen, L.; Marsden, T. Constructing sustainable communities: A theoretical exploration of the bio-economy and eco-economy paradigms. Local Environ. 2011, 16, 8. [CrossRef]

68. Dietz, T.; Börner, J.; Förster, J.; Von, B.J. Governance of the Bioeconomy: A Global Comparative Study of National Bioeconomy Strategies. Sustainability 2018, 10, 3190. [CrossRef]

69. Bugge, M.; Hansen, T.; Klitkou, A. What is the bioeconomy? A review of the literature. Sustainability 2016, 8, 691. [CrossRef]

70. Vivien, F.D.; Nieddu, M.; Befort, N.; Debref, R.; Giampietro, M. The hijacking of the bioeconomy. Ecol. Econ. 2019, 159, 189-197. [CrossRef]

71. Duchesne, L.C.; Wetzel, S. Managing timber and non-timber forest product resources in Canada's forests: Needs for integration and research. For. Chron. 2002, 78, 837-842. [CrossRef]

72. Gautham, K.H.; Watanabe, T. Silviculture for non-timber forest products management: Challenges and opportunities for sustainable forest management. For. Chron. 2002, 78, 830-832. [CrossRef]

73. Luc, C.D.; Suzanne, W. The bioeconomy and the forestry sector: Changing markets and new opportunities. For. Chron. 2003, 79, 860-864. [CrossRef]

74. Chamberlain, J.L.; Dietrich, D.; Kathrin, M. Rediscovering the Contributions of Forests and Trees to Transition Global Food Systems. Forests 2020, 11, 1098. [CrossRef]

75. Mohi-ud-din, R.; Ashraf, R. Protection of medicinal plants: A legal perspective in the state of Jammu \& Kashmir. Int. J. Pharm. Sci. Res. 2019, 10, 1089-1094.

76. Peerzada, I.A. Contribution of NTFPs in Livelihood and Household Income of Forest Fringe Communities in Bangus Landscape of Kashmir Himalayan forests. Harnessing Nat. 2020, 2, 39-40.

77. Gangoo, S.A.; Islam, M.A.; Tahir, M. Wealth of Non Timber Forest Products and their Trade in Jammu and Kashmir. Ind. For. 2017, $143,827-833$.

78. Nilsson, P.; Cory, N.; Stendahl, J. Digest of Forest Statistics; 2017-2019; J\&K Forest Department, Government of J\&K: Srinagar, India, 2020.

79. HFRP (Harvard Family Research Project). Evaluating an Issue's Position on the Policy Agenda: The Bellwether Methodology. The Evaluation Exchange. Issue Topic: Advocacy and Policy Change. Volume XIII, Numbers 1 and 2, Spring 2007. Harvard Graduate School of Education. Available online: https://archive.globalfrp.org/evaluation/the-evaluation-exchange/issue-archive/ advocacy-and-policy-change/evaluating-an-issue-s-position-on-the-policy-agenda-the-bellwether-methodology (accessed on 12 July 2020).

80. Gundimeda, H.; Sanyal, S.; Sinha, R.; Sukhdev, P. The Value of Timber, Carbon, Fuelwood and Non-Timber Forest Products in India's Forests; Monograph 1, Green Accounting for Indian States Project: Chennai, India, 2005.

81. Verma, M.; Kumar, V. Natural Resource Accounting of Land and Forestry Sector (Excluding Mining) for the States of Madhya Pradesh and Himachal Pradesh; CSO/MOSP, Government of India: New Delhi, India, 2006.

82. Wu, S.; Hou, Y.; Yuan, G. Valuation of Forest Ecosystem Goods and Services and Forest Natural Capital of the Beijing Municipality, China. Unasylva 234/235 2010, 61, 28-36.

83. Biggs, A.G. An options pricing method for calculating the market price of public sector pension liabilities. Publ. Budg. Fin. 2011, 31, 94-118. [CrossRef]

84. NBA. Economic Valuation of Bio-Resources for Access and Benefit Sharing. National Biodiversity Authority (NBA). 2018. Available online: http:/ / nbaindia.org/unep-gef/pub1/brief.pdf (accessed on 12 July 2020).

85. Tali, B.A.; Khuroo, A.A.; Ganie, A.H.; Nawchoo, I.A. Diversity, distribution and traditional uses of medicinal plants in Jammu and Kashmir (J\&K) state of Indian Himalayas. J. Herb. Med. 2019, 17-18, 100280.

86. Kaul, M.K. Medicinal Plants of Kashmir and Ladakh-Temperate and Cold Rid Himalaya; Indus Publications: New Delhi, India, 1997; p. 42.

87. Dar, P.A.; Nahida, R.; Athar, P.; Afsahul, K. Ethnomedicinal Practices of Kashmir valley: A Review. J. Pharmacog. Phytochem. 2018, 7, 278-284. 
88. AAR. Annual Administration Report of Jammu \& Kashmir Forest Department; DFO Statistics at Principal Chief Conservator of Forests, J\&K Government: Srinagar, India, 2011.

89. Gairola, S.; Sharma, J.; Bedi, Y.S. A cross-cultural analysis of Jammu, Kashmir and Ladakh (India) medicinal plant use. J. Ethnopharm. 2014, 155, 925-986. [CrossRef]

90. Chopra, K. Measuring Contribution of Informal Sector/Informal Employment to GDP-Informal Sector Contribution to GDP: A Study of the Forestry; Sector (Paper No. 3) Expert Group on Informal Sector Statistics (Delhi Group) 11-12 May 2006; Ministry of Statistics and Programme Implementation, Government of India: New Delhi, India, 2006.

91. Dar, A.K.; Hassan, W.; Lone, A.H.; Haji, A.; Manzoor, N.; Mir, A.I. Study to assess high demand and high commercial value Medicinal Plants of Jammu and Kashmir India-With special focus on routes of procurement and identification. Int. J. Res. Dev. Pharm. Life Sci. 2017, 6, 2576-2585. [CrossRef]

92. Sharma, O.P. State of Environment and Its Related Issues in J\&K. In JEK ENVIS News Letter; Department of Ecology, Environment and Remote Sensing: Jammu and Kashmir, India, 2018.

93. ICFRE. Forest Development Corporations. Forest Sector Report India. 2010. Available online: http://www.frienvis.nic.in/ Database/Forest-Development-Corporations_1824.aspx (accessed on 12 July 2020).

94. Mishra, M.; Shrivastava, M. Trade of minor forest products in the rural markets of central India. Biol. Forum $2015,7,516$.

95. Ripple, W.J.; Wolf, C.; Newsome, T.M.; Galetti, M.; Alamgir, M.; Crist, E.; Mahmoud, M.I.; Laurance, W.F. 15364 Scientist Signatories from 184 Countries. World Scientists' Warning to Humanity: A second notice. Biol. Sci. 2017, 67, $1026-1028$.

96. Yadav, M. Creating Peoples' Brand: The Case of Vindhya Valley/Herbal. Nirma Univ. J. Bus. Manag. Stud. 2007, 1, 71-83.

97. TRAFFIC. News Letter on Wildlife Trade in India: Special Issue on Medicinal Plants. 2019, Volume 13. Available online: https: / / www.researchgate.net/publication/335095621_Trade_in_Medicinal_and_Aromatic_plants_of_India_An_overview (accessed on 12 July 2020).

98. Mangoale, R.M.; Afolayan, A.J. Comparative Phytochemical Constituents and Antioxidant Activity of Wild and Cultivated Alepidea amatymbica Eckl \& Zeyh. BioMed Res. Int. 2020, 2020, 5808624. [CrossRef] [PubMed]

99. Chen, H.P.; Yang, K.; Zheng, L.S.; You, C.X.; Cai, Q.; Wang, C.F. Repellant and insecticidal activities of shyobunone and isoshyobunone derived from the essential oil of Acorus calamus rhizomes. Pharmacogn. Mag. 2015, 11, 675-681.

100. Sanjay, P.; Isaivani, I.; Deepa, K.; Madhavan, J.; Senthil, S. The preparation of dye sensitized solar cells using natural dyes extracted from Phytolacca icosandra and Phyllanthus reticulatus with ZnO as photoanode. Mater. Lett. 2019, 244, 142-146. [CrossRef]

101. Joshi, R.K. Angelica (Angelica glauca and A. archangelica) Oils. In Essential Oils in Food Preservation, Flavor and Safety; Preedy, V.R., Ed.; Elsevier: Amsterdam, The Netherlands, 2016; pp. 203-208. 